\title{
PHYSICAL COURAGE IN JAMES DASHNER'S NOVEL THE MAZE RUNNER
}

\author{
Ali Sadikin Berutu, Muhammad Amrin Siregar \\ Faculty of Literature, Universitas Islam Sumatra Utara, Medan, Indonesia \\ e-mail: brutubisnis@gmail.com
}

\begin{abstract}
This research is concerned with Protagonist's Physical Courage found in James Dashner's novel The Maze Runner first published in 2009. It is described in the novel that the Protagonist of the novel has shown his physical courage in a Glade which is always haunted or attacked by dangerous creatures called Grievers. Because of his great courage, he has been able to influence his friends to fight with the Grievers. He is even admired by his friends, all the Gladers. He can even finally be able to escape together with them to live freely outside the place that has already imprisoned them in it. This research uses a qualitative research method proposed by Creswell: defining this method as a means for exploring and understanding the meaning individuals or group ascribe to a social or human problem. After having analyzed the variable in the novel, it can be concluded that the protagonist shows two forms of physical courage. They are selfishness and being one own-self.
\end{abstract}

Keywords: Courage, Physical Courage, Bravery

\section{Introduction}

This study is about physical courage which is found in the novel The Maze Runner written by American author, James Dashner. This novel was first published by Delacorte Press Books, New York in 2009.

Because this study is concerned with courage, it is better to know first what the term courage is. According to Paul (2010: 1), courage is the state or quality of mind or spirit that enables a person to face difficulty, danger, pain orvicissitudes with self-possession without fear. Courage can also be defined as the mental or moral strength of venture, persevere, and withstand-danger, fear, or difficulty. Courage is something we all admire. When asked to describe courage, most people conjureup the image of a character like Batman or Superman and describe it as a state or condition of being a hero. Everybody sees courage differently but when asked to go deeper to really define courage; the only response that comes to this mind is that it is a beautiful act that only after it is finished you can see the beauty.

Courage is one of the themes of James Dashner's novel The Maze Runner. It is described in the novel that to be in the Glade everybody has to be extremely courageous or fearless. They have to face what is happening and to face it right away strong and fierce. Alby, one of the main characters of the novel, says that if somebody is not scared, then they are not human. He means to say that fear is one of the things the Gladers face throughout the novel but every last one of them is brave and they are strong and most of them will fight until the end. Courage means to have bravery and conduct not to be afraid. Courage is being able to do something and Thomas, the protagonist of the novel, can do 
that. He is not afraid to try new things. The Gladers always put fear behind them and courage ahead.

In the novel, it can be seen that confidence and courage lead to fulfilling dreams. To start with, Thomas decided to be a Runner, and the Gladers do not support his dream. When he becomes a Runner, Chuck congratulates him by saying that the first night, when he is bragging about being a Runner, he is laughing inside so hard. Thus, he proves him wrong, In order for Thomas to complete his dream, he needs to have confidence. Furthermore, Thomas displayes courage when he jumps in front of the Grievers. He does this because the Gladers need his memories in order to escape from the Maze. Being stung by the Grievers created plenty of pain, but it displays sufficient courage and masses of confidence. Another representation of Thomas's bravery is when he helps lead the escape from the Maze. Thomas assists as the Keepers decipher the clues given to them by the Creators. He creates some of these ways to interpret the clues using his knowledge from his newly recovered memories, and he demonstrates valor and self-belief. Thus, because of the Gladers reaching their dreams, demonstrating bravery, and assisting in the escape, a theme is to always fulfill your dreams with courage and confidence.

It is also found in the novel that exceptional friends are always reliable. For instance, as the Gladers fight the Grievers, Thomas and Teresa needed to go through the fight. Thomastells Teresa to let them do the fighting and they have to get through the Griever's Hole. They trust the fighting Gladers to keep them safe. Another illustration of dependable friends is as she punches in the code words to save the Gladers, Teresa depends on Thomas and Chuck to save her from the Grievers. Thomas and Chuck slay multiple Grievers in order to protect Teresa, and thisshows how Thomas and Chuck are reliable. Furthermore, when Alby passes out from being stung by the Grievers, he relies on Thomas and Minho to protect him from the Maze and its inhabitants. Thomas saves Alby throughout the night in the Maze and earns his trust. Thus, this can be meant that exceptional friends are always dependable.

After reading the novel, it is found that courage is a good thing that should be owned by everybody if they want to get something or to be successful in their effort or struggle. Everyone should be the hero in their own life. And being a hero they have to struggle. In line with this, Aldrich (2014) in Sawira at. al. (2017) says that life is struggle, sometimes you have to lose something in order to get something, but it's always your choice to consider what you want or need the most. Such struggle will be successfully achieved when there is a courage. This becomes the reason why the writer has chosen the matter about courage as described in the novel to be studied. Because of their courage, Thomas and his friends, the other Gladers can finally come out or escape from the Maze in which they have already suffered much. Thus, this study concerns the forms of the protagonist's physical courage in the novel.

\section{Literature Review}

\subsection{Courage}

Paul (2010: 2) writes that courage comes in different ways. Being courageous can be from surviving through cancer to a child rescuing his dog from a busy street, and also towards people that are judging others by what they do, wear or say. Courage is also doing some brave deed without thinking about what the consequences could be. She explains that we have all faced the challenge to be courageous, and being courageous is not always easy because it takes heart to do a courageous act. For example, many people claim President Obama as a courageous person, for having the confidence, determination and 
faith he possesses, to takecourageous decisions like to grant innocent, undocumented youth protection from deportation,according to the New York Times. A person that is going through a lot more every single day and anyway is looking forward is a courageous person.

Courage is an important virtue to practice in life because it leads to many rewards, like success. It gives us strength to act more decisively. Courage is the key to success. It is the answer towards getting the success that is always wanted. Great things are achieved by being courageous and self-confident. If you believe that courage can lead to success you should apply it even in the small decisions that you do in your everyday life. During your lifetime you might meet people that will try to make you think you wrong but being able to stand and say what you exactly think is a courageous act. Whatever you do, you need courage. Whatever course you decide upon, there is always someone to tell you that you are wrong. There are always difficulties arising that tempt you to believe your critics are right. To map out a course of action and follow it to an end requires some of the same courage that a soldier needs. Peace has its victories, but it takes brave men and women to win them.

Based onher knowledge and prior understanding, Paul believes that doing an act of courage is the greatest feeling ever and only that act can give you faith and determination to accomplish great things. She believes that her courage is the spirit that enables her to face the difficulties and pain oflife.

It can also be defined that courage is strength of anima - both mental and moralto venture and persevere, to act in the face of fear, danger, and overwhelming difficulty. Itis confirmed that Confucius ever said that "it does not matter how slow you go so long as you do not stop" (Simonpietri, 2013: 1).

Courage can be classified into physical courage and moral courage. Physical courage is bravery in the face of physical pain, hardship, death or threat of death; while, moral courage is the ability to act rightly in the face of popular opposition, shame, scandal, discouragement, or personal loss.

In the Western tradition, notable thoughts on courage have come from philosophers, Socrates, Plato, Aristotle, Aquinas, and Kierkegaard; in the Eastern tradition, some thoughts on courage were offered by the Tao Te Ching. More recently, courage has been explored by the discipline of psychology.

Courage remains a difficult construct to accurately and categorically define for social researchers, psychologists, theologians, and philosophers alike (Woodard \& Pury, 2007).

Scholars, politicians, and laypeople have all enteredthe debate over how to define courage. Some believethat American culture over the last 30 years or sohas defined courage. That is, courage has been" attributed to all manner of actions that may indeedbe admirable but hardly compare to the consciousself-sacrifice on behalf of something greater than self-interest'" (McCain \& Salter, 2004: 13). At thesame time, others would argue that courage can beattributed not only to theoccasional and isolated actof rescue or self-sacrifice, but also to everyday acts(Evans \& White, 1981: 419; Putman, 2001: 463; Woodard, 2004: 173). Defining courage in terms of character strengths (bravery, persistence, integrity, and vitality)of human goodness and excellence, the positivepsychology movement endeavors to view couragethrough the lenses of positive subjective experiences,positive individual traits, and institutions that enablepositive experiences and positive traits (Peterson \& Seligman, 2004; Seligman \& Csikszentmihalyi, 2000: 5). 
In the course of investigating the concept ofcourage, we uncovered numerous definitions ordescriptions of courage of which 29 are listed inHemingway's description of courage as "grace under pressure" (cited in Lopez, O'Byrne, \&Peterson, 2003: 191). This marks the simplest, yeteloquent, example. A more complex, multidimensional definition of courage as "the disposition tovoluntarily act, perhaps fearfully, in a dangerouscircumstance, where the relevant risks are reasonablyappraised, in an effort to obtain or preserve someperceived good for oneself or others recognizing thatthe desired perceived good may not be realized''(Shelp, 1984: 351).

Though, numerous definitions of courage provide a rich foundation from which to build, we remain ata loss for an operational definition of this constructon which to base sound explicit theories. Even withall of the attempts to define courage, we have notadvanced the domain to an agreed-upon conceptualdefinition. Lopez and colleagues correctly assert that "though we have been able to parse out the differenttypes of courage by establishing between-branddifferences, we have been less successful at determining the elements or components of courage. Thus, what is common to all brands remains unclear''(Lopez et al., 2003: 189). Operational definitionsof constructs of interest are essential to good researchand a lack of coherence in courage definitions is anobstacle to the advancement of research. Therefore,the search for a common structure of courage(apparently underlying the disagreement as topeople's implicit theories of courage) forms a majorfocus of the current investigation.

\subsection{Physical Courage}

This is the courage most people think of first: bravery at the risk of bodily harm or death. It involves developing physical strength, resiliency, and awareness.

Physical courage is the type most people think of first, the one that allows us to risk discomfort, injury, pain or even death - running into burning buildings as a firefighter, facing an enemy on the battlefield, undergoing chemotherapy, climbing a mountain, protecting a child from a dangerous animal. We are right to be wary of pain: pain tells us where our boundaries and limits are. However, sometimes there are things more important than pain, and our physical fear becomes a border to be crossed. Physical fear is often blown entirely out of proportion: pain is often greater in anticipation than in fact, and that dread can become an insurmountable barrier.

Physical courage also involves recognizing that your body is how you participate in the world; keeping it healthy, strong, and resilient prepares you for all kinds of challenges, not just physical ones.

\section{Research Method}

Creswell (2009: 3) proposes that there are three types of research designs. They are qualitative, quantitative, and mixed methods. In this study, the writer applies one of them, that is, qualitative research method. According to him (2009: 4), qualitative research is a means for exploring and understanding the meaning individuals or groups ascribe to a social or human problem. The process of research involves emerging questions and procedures, data typically collected in the participant's setting, data analysis inductively building from particulars to general themes, and the researcher making interpretations of the meaning of the data used. 


\section{Discussion}

\subsection{Selflessness}

This type of physical courage is shown by Thomas though he does not know very much about the real characters of the boys in the Glade. He realizes well that he cannot be selfish in such a horrible place. Since his first time to be in the Glade, the place that is very strange for him, he has been saved or helped by most of the boys (or the Gladers) whom he does not recognize well.

When Alby and Minho are informed not to have returned from the Maze, he feels worried. It is because he has known that the place is very dangerous and it is also very possible for every Glader to be killed by wild Grievers. Realizing what will possibly happen to Albyan Minho, Thomas decides to help them even though he is forbidden to do it.

Thomas shakes his head and turns back to see the Maze. He does not really know Alby and Minho, but his chest aches thinking they are out there because they can be killed by the terrifying creatures he has ever seen through the window when he first arrived in the Glade.He is surprised from the daydream when a loudringing sound comes from all directions. Then the sound crackles and the rocks cracks and the doors will soon close that night.

He is amazed at the moving wall. In such a moment, he suddenly catches a glimps of the movement. Something moves fast inside the Maze, along the long hallway in front of it. Finally he can see clearly that it is Minho who is embracing Alby's hand in his shoulder. Minho calls him and tells him that Alby has already been hurt by the Grievers. He feels very sad to see them. Then, at the moment the door of the Glade is about to close, he comes into the Maze without caring the prohibition cried by Newt, another Glader. He is desperate to do that for the sake of helping them, especially Alby who has ever saved him from the brutal attack of Ben, the crazed Glader. This moment when he shows his carelessness to anybody around him can be described through the quotation below.

Alby, on the ground, looked worse, his clothes ripped, his arms covered with cuts and bruises. Thomas suddered.HadAlby been attacked by a Griever? "Greene," Minho said, "ifyou think that was brave comin' out here, listen up. You'rethe shuckiest shuck-faced shuck there ever was. You're as good as dead, just like us." Thomas felt his face heat uphe'dexpected at least a little gratitude. "I couldn't just sit there andleave you guys out here." "And what good are you with us?"Minho rolled his eyes. "Whatever, dude. Break the Number One Rule, kill yourself, whatever." "You're welcome. I was just tryingto help." Thomas feels like kicking him in the face. (Dashner, 2009: 71)

As described in the above quotation, it can be seen that Thomas is really brave to come into the Maze, a few second before the Glade is closed tightly. He does not care what will happen to himself later even though Newt has already prohibited him not to come into the Maze. His willingness to help Alby and Minho is greater than the threat or prohibition from Newt.

Thomas, however, feels angry at Minho's pessimistic nature. He is disappointed to see Minho who has underestimated his efforts to help them get out of the Maze that always threatens their lives. He actually wants him to show his gratitude to him but instead he hears that Minho still blames him to have done something stupid to help them 
in the Maze, the place which is very dangerous for all of them. Nevertheless, he remains to be patient to face the bad character of Minho who cannot believe his courage.

Thomas gets surprised to find the reality that Minho is selfish. Minho leaves him and Alby who is in a very bad condition after being attacked by the Grievers. It means that Minho does not care very much about the accident undergone by Alby. Thomas knows well that before the attack of the Grievers, Minho and Alby went together to the Maze to search for the death body of a Griever and the existence of Ben in the Maze. The togetherness that he has shown is useless because Minho finally leaves Alby at the moment he really needs his help.

He then sees Albywho looks very weak and cannot do anything. He slumps near the stone wall. Because of being very worried about Alby's condition, he feels Alby's neck to find out if his pulse is still throbbing. He feels happy because Alby is still alive. He has no heart to leave him alone and tries to help him go out from the Maze even though he does not know where to go. This is, of course, the form of his selflessness, and this can be described through the quotation below.

He couldn't leave a friend to die. Even someone as crankyas Alby. He reached down and grabbed both of Alby's arms, squatted into a sitting position and wrapped the armsaround his neck from behind. He pulled the lifeless bodyonto his back and pushed with his legs, grunting with theeffort. But it was too much. Thomas collapsed forward ontohis face; Alby sprawled to the side with a loud flump. Thefrightening sounds of the Grievers grew closer by the second,echoing of the stone walls of the Maze. (Dashner, 2009: 75)

The above quotation becomes another proof that Thomas is not a selfish boy. He shows his selflessness by giving his care to Alby who should be saved by him. He has no heart to leave him alone in his very bad condition. He is afraid that the Grievers will attack him again. In order to help him, he pulls Alby's body onto his back and pushes with his legs. However, he collapses and Alby sprawls. Because he hears the loud horrible sounds coming closer, he grabs Alby's arm again and starts dragging him along the ground.

\subsection{Courage to Be One Own-Self}

At the first time he finds himself in the Glade, Thomas feels very confused and scared. He does not know where he is. He looks in every direction; however, he can only see darkness and tries to search for a way out. He can see nothing except to feel the cool metal around him. He then groans in frustration; his echo amplifies through the air like the haunted moan of death. The situation really makes him scared. Then he screams, calls for a help, and pounds on the wall with his fists.

A few minutes later, a number of teenagers come to help him, but he recognizes no one of them. He even sees that most of them do not like to see him. Their facial expressions which are not nice to see really make him restless and scared. Some of them talk to him in a rude manner, but he does not know what he must say to them. He is also afraid that they will do something bad to him if he uses rude words to them. In order to have some friends, he tries to be closer to some of them, and finally they want to be his friends.

Though there are two or three persons who always accompany him wherever he is, they often say something rude or impolite to him. He has no bravery to challenge them in order not to do or say something bad or inappropriate words to him. They even tell 
something bad or terrible about what there are in the glade or the maze. Consequently, he always feels restless and scared. Up to this moment, he does not know what he has to do even though he really wants to know many things in this scary place.

His courage can finally be seen. This is found in the moment when he encourages himself to see some tombs in a place which is very dark. It is late in the evening and he walks from one tomb to another tomb while looking at the names written on the wooden bars. He looks around and sees that there are dozens of other tombs. He even finds a tomb in which there is the remains of a decaying body. In such a moment, he hears a sound or snap coming closer to him. He gets very surprised and shouts to the unknown figure to appear but it does not want to appear in front of him. After some minutes later, however, he is suddenly attacked by a thin boy who looks terrible. Realizing what is happening he makes a reaction to protect himself even though the thin boy is able to beat him. He is then slammed to the ground and feels a wood cross his back and it scratches his skin until bleeding. He fights back by pushing and hitting his attacker hard. This courage of him can be proved through the quotation below.

He pushed and swatted at his attacker, a relentless jumble of skin and bones cavorting on top of him as he tried to gain purchase. It seemed like a monster, a horror from a nightmare, but Thomas knew it had to be a Glader, someone who'd completely lost his mind. He heard teeth snapping open and closed, a horrific clack, clack, clack. Then he felt the jarring dagger of pain as the boy's mouth found a home, bit deeply into Thomas's shoulder. (Dashner, 2009: 46)

In the above quotation, it is described that Thomas can be seen to have courage to be himself to fight with the unknown person who attacks her suddenly. This means that he is not frightened to see something horrible and to face any attacker even though he is alone in such a situation.

The unknown attacker really hits him and causes pain like a burst of adrenaline through his blood. Thomas plants the palms of his hands against his attacker's chest and pushes, straightening his arms until his muscles strain against the struggling figure above him. Finally the kid falls back and then he can see clearly the face of the crazed attacker.

He later knows that the Glader who has attacked him is Ben, a thin crazed Glader. He is informed that Ben is always alone and attacks a new comer in the Glade. His attack is very dangerous and it can kill somebody he is attacking. However, Thomas tries to be careful to him and wants to know what make him behave in such a dangerous way.

After the analysis of the subject matter of this study, the writer can make several findings that need to be known by the readers of this study. Because of their courage, Thomas and his friends can go out or escape from the maze in which they have ever suffered very much. Thomas can save one of the Gladers whose name is Alby. He has saved him from the attack of the Grievers that want to kill him. It is found that Thomas is not a selfish boy. He does not want to keep silent meanwhile his friends Alby and Minho are in danger out of the Glade. Because of having courage, he searches and helps them. The courage that he has makes him confident to do something which is useful for himself and other people, successful in his efforts, and finally happy after he gets his success. Thomas is admired by most of the Gladers because he is one of the Gladers who is quite courageous to come into the Glade to save the soul of Alby. 
Physical Courage in James Dashner's Novel The Maze Runner, Ali Sadikin Berutu, Muhammad Amrin Siregar

\section{Conclusion}

Courage, whatever form it is, should be owned by everyone in order that they can get or achieve what they want to, they can win a competition, they can set aside all obstacles in front of them, and they can even be very helpful or useful for other people. Courageous people always feel confident when facing various problems and trying to solve them. In other words, they will not usually feel afraid of facing any of the problems. When they are successful to overcome them, they will usually feel very happy. Most of the people who are courageous show their eagerness to help other people. In other words, they are not selfish. They are sure that they can do many things to help others. Being courageous to face various forms of problems constitutes a very valuable experience that should be shown by anyone at least once in a lifetime.

\section{References}

Bone, Alex. (2017). Seven Benefits to Having Courage. auburnspride.blogspot.com./2015/11/7-benefits-of-having-courage.html.

Britton, Christian. (2014). The Many forms of Bravery. Themanyformsofbraverychristianb.weebly.com/bravery-in-the-maze-runner.html.

Creswell, John W. (2009). Research Design: Qualitative, Quantitative, and Mixed Methods Approaches.Third Edition. London: SAGE Publications Inc.

Dashner, James. (2009).The Maze Runner. New York: Delacorte Press Books United States.

Evans, P. D. \& White, D. G. (1981). Towards an Empirical Definition of Courage. Behavioral Research and Therapy, 19, 419-424.

Gould, N. H. (2005). Courage: Its Nature and Development. Journal of Humanistic Counseling, Education and Development, 33, 102-116.

Lopez, S. J. et al. (2003). Profiling Courage. In S. J. Lopez \& C. R. Snyder (Eds.), Positive Psychological Assessment: A Handbook of Models and Measures (pp. 185-197). Washington, DC: American Psychological Association.

McCain, J., \& Salter, M. (2004). Why Courage Matters: The Way to a Braver Life. New York: Random House, Inc.

Miles, M. B \&Huberman, A. M. (1994). Qualitative Data Analysis. 2nd Ed. Newbury Park, CA: Sage.

Paul, Christie. (2010). Courage. New York: Queens-borough Community College.

Peterson, C. \& Seligman, M. E. P. (2004). Character Strengths and Virtues: A Handbook and Classification. New York: Oxford University Press.

Putman, D. (2001). The Emotions of Courage. Journal of Social Philosophy, 32, 463-470.

Sawira, Suhadi, J., and Manugeren, M. (2017). Heroism in Lin Carter's Novel The Quest of Kadji: Language Literacy, 1(1), $119-140$, DOI: https://doi.org/10.30743/11.v1i1.249 https://jurnal.uisu.ac.id/index.php/languageliteracy/article/view/249/249

Shelp, E. E. (1984). Courage: A Neglected Virtue in the Patient-Physician Relationship. Social Science and Medicine, 18, 351-360.

Simonpietry, Javier. (2013). Courage and Fear.Conference Paper. DOI: 10.13140/2. 1. 2852. 3845.

Sligman, M. E. P. And Csikszentmihalyi, M. (2000). Positive Psychology: An Introduction. American Psychologist, 55, 5-14.

Woodard, C. R. (2004). Hardiness and the Concept of Courage.Consulting Psychology Journal: Practice and Research, 56, 173-178. 